\title{
LAW SCHOOL LEGAL AID CLINICS: \\ A SAMPLE PLAN; THEIR LEGAL STATUS
}

\author{
HerberRT M. SHVERBERG †
}

By describing the organization and operation of a successful law school legal aid clinic, this article offers information to schools which might want to establish or modify legal aid clinics of their own. The discussion includes typical modes of clinic transactions with clients, and raises certain problems concerning the legal status of the clinics and their activities.

\section{The Prison Research Council of the University of Pennsylvania Law School}

\section{A. Genesis}

Four different needs gave birth to the Prison Research Council of the University of Pennsylvania Law School. First, a United States District Judge felt himself unable to give proper attention to the many letters sent him by unhappy "alumni" of his court. Second, The Bureau of Prisons of the United States Department of Justice was concerned that prisoners in its custody have adequate access to legal materials and legal advice. Third, an increasing number of letters from prisoners seeking help were received by the Dean of the Law School, the law library, and the various faculty members whose publications or public activities had come to the inmates' attention. Fourth, a group of students who did not qualify for law review work on the basis of first year exams were not content to participate in classes and nothing more; they sought useful activity which could provide an enriching experience comparable to that of law review participation. This last element is by far the most significant. Any law school which has a nucleus of students willing to work at extending their legal educations beyond the classroom confines, and which is willing to support the students in an effort to do so, can establish a legal aid clinic. While the University of Pennsylvania Law School was fortunate in having the opportunity affirmatively presented to it, interested law schools should have little difficulty beginning.

$\dagger$ Formerly Chairman, Prison Research Council, University of Pennsylvania Law School. A.B. 1961, University of Pennsylvania. LL.B. 1968, University of Pennsylvania. Member, District of Columbia Bar. 
The Prison Research Council traces its origins to 1965, when a program was established at the United States Penitentiary in Leavenworth, Kansas, in which students at the University of Kansas Law School began to provide legal assistance to Leavenworth inmates. ${ }^{1}$ The initial success of this program encouraged Eugene N. Barkin, Legal Counsel of the United States Bureau of Prisons, Department of Justice, to seek the establishment of similar programs elsewhere. The Federal Penitentiary at Lewisburg, Pennsylvania, had a need for such a program, and Mr. Barkin began to look into the possibilities. At approximately the same time, United States District Judge Francis L. Van Dusen, ${ }^{2}$ who had sentenced a number of convicts to Lewisburg, began to discuss the increasing number of letters sent to him by prisoners seeking answers to legal questions with Professor Curtis $R$. Reitz, who has had a scholarly interest in the federal habeas corpus remedy. Some method of attending to these letters was necessary, but extended correspondence between the judge and a large number of prisoners with legal inquiries was impossible. Professor Reitz, aware that similar letters were being addressed to the school with increasing frequency, undertook to determine the extent of student interest in the problem. Discussions among Lewisburg Warden J. J. Parker, Judge Van Dusen, Professor Reitz and Mr. Barkin led to the establishment of an experimental prisoner aid project at the Lewisburg Penitentiary. Letters from prisoners would be forwarded to Professor Reitz, who would attempt to interest a student in researching, under his guidance, the legal issues involved, and in drafting and sending an opinion letter to the prisoner. Forms were prepared to aid the prisoner in presenting his problem, and the program was publicized to the prison population.

The first prisoner letters and the end of the school year arrived simultaneously; by the middle of the summer, about eighty letters had been received, and they continued to arrive. It soon became clear that only a major effort could keep the project from sinking under its own weight shortly after the launching. A number of students, ineligible for the law review but reluctant to forego extracurricular challenge, requested and received permission to run the prisoner response program. The Prison Research Council was born.

While the Lewisburg Penitentiary population provided a ready source of clients, it was by no means the only source. Due to the "vaunted "prison grapevine,", 3 the Council soon had letters from

1 See Wilson, Legal Assistance Project at Leavenworth, 24 LEGAL AID BRIEF CAse 254 (1966).

2 Now Circuit Judge, United States Court of Appeals for the Third Circuit.

3 N. Leopold, Life Plus 99 Years 271-72 (Popular Library ed. 1957). 
various Pennsylvania prisons and, thereafter, from many more prisons on the eastern seaboard. Two years later, the Council's correspondence extended to more than 1,000 prisoners ${ }^{4}$ in institutions spread as far as California, Oregon, Wisconsin, New York, Florida, Missouri, and Louisiana. The Council's program has now expanded to reach inmates of more than 100 state and federal institutions. ${ }^{5}$

\section{B. Some Basic Choices}

The establishment of a law school legal aid clinic presents a number of organizational options requiring careful analysis. In the case of the Prison Research Council, four basic organizational approaches have been followed. First, the services are conducted essentially by mail with very limited personal contact between "counsel" and client. Second, the student function is limited to a research and writing "practice," rather than one involving actual courtroom representation of clients. Third, the Council has limited its clientele to prisoners. Fourth, the clinic has operated on its own, avoiding affiliation with a community agency such as the Voluntary Defender. Each of these characteristics of the Council was consciously chosen on the basis of carefully weighed policy considerations.

\section{Correspondence or Personal Consultation?}

From the outset the Council sought to provide its participants with the same kind of research, writing and editing opportunities available to law review editors. Written correspondence obviously lends itself to such an experience. Each prisoner's problem results in a legal memorandum upon which the Council's opinion letter is based. The thoroughness of the research job is facilitated by the reflective process which written correspondence entails. By exchanging letters with the client the Council seeks to develop enough facts to permit identification and analysis of the relevant issues. Several students criticize and edit the research during its various stages. Unlike the personal interview situation, correspodence generates little pressure to give answers that one is "pretty sure of," based on the results of earlier research on another case. When the Council has been forced

4 Nazarro, Gentlemen: I believe that I have been sentenced illegally . . . . The [Philadelphia] Sunday Bulletin, May 18, 1969, (Magazine), at 6, col. 1 .

5 Id. The expansion of the Prison Research Council's clientele was, no doubt, facilitated by its initial liaison with a federal penitentiary. Federal prisoners are transferred to other institutions within the federal correctional system and are also released to state authorities throughout the country. This provides a very efficient "grapevine." The phenomenon doubtless exists within more localized systems, but the spread of information probably comes about more gradually. The assertion of availability of clients is made with the knowledge that a clinic may find its initial group of clients to be somewhat limited; this will likely be only a temporary condition. 
to do personal interviewing (e.g., because a prisoner is blind, does not speak or write English well, or wishes to describe a situation he does not feel can be committed wisely to writing), this type of pressure has been felt; it has been intensified by the poignancy of some of the prisoners' situations. The desire to reassure by providing an immediate answer is tempered by distance. A certain necessary detachment becomes possible when any communication with a prisoner must, before being undertaken, pass the muster of student colleagues and faculty advisors. Finally, centralization of activity at the law school is decidedly more efficient in conserving student time and energy than expensive and time-consuming personal visits to prisons, however conveniently situated. Nor is there a feeling that personal consultation would improve the quality of service rendered. Even though extensive personal interviewing would provide valuable experience in a vital professional skill, the liabilities of interviewing seem to outweigh the assets.

\section{Should Students Represent Clients at Trial?}

In at least thirteen states students are actually permitted to represent clients in trial courts under the supervision of a practicing attorney. In some states a certified attorney must be present in the courtroom; in others he need not be. ${ }^{6}$ Some of the pros and cons of student representation of clients at trial have been discussed by Professor Henry Monaghan of Boston University Law School. ${ }^{7}$ While one can only qualifiedly agree with Professor Monaghan that " $[\mathrm{a}] \mathrm{t}$ the trial itself the law school student is in a position essentially no different from the relatively young member of the bar, except that he has had more careful supervision," 8 one is nevertheless persuaded by what follows:

Perhaps in an ideal system only experienced lawyers should represent criminal defendants. But we are far from that millennium; our society simply cannot afford to read the sixth amendment [as interpreted in Gideon v. Wainwright ${ }^{9}$ ], or any other constitutional provision, as mandating "the assistance of experienced counsel." Moreover, such a view wrongly

- See Law Students in Court, 24 Legal AId Brief CASe 266 (1966).

7 Monaghan, Gideon's Army: Student Soldiers, 45 B.U.L. REv. 445 (1965) [hereinafter cited as Monaghan]. See also Broden, A Role for Law Schools in OEO's Legal Services Program, 41 Notre DaMe LAw. 898 (1966); Cleary, Law Students in Criminal Law Practice, 16 DePaul L. Rev. 1 (1966); Note, 12 WAYNE St. L. REV. 519 (1966), for similar discussions of possible student roles.

8 Monaghan, supra note 7 , at 460 . This assertion is not completely accurate, unless the student practitioner is subject to the lawyer's professional ethical code and unless he is liable to his client for damages in the event of malpractice. These subjects, which are not dealt with by Professor Monaghan, are considered in part II infra.

9372 U.S. 335 (1963). 
equates experience with competence and, more importantly, inexperience with incompetence." 10

However, while competence and experience are not coextensive, there is clearly an element of true competence which only experience can provide. The fact that mere inexperience has not yet been held to disqualify a lawyer from being appointed to represent a client ${ }^{11}$ may be due more to the social economics of the situation (i.e., too few experienced lawyers) than to a value judgment that competence does not depend upon experience. Monaghan himself would bar representation by inexperienced trial lawyers in "cases carrying heavy penalties," 12 but this distinction seems superficial when the effect of "habitual offender" statutes ${ }^{13}$ and the social consequences of even a "minor" conviction are considered. It is somewhat cynical, moreover, to decide that a person has so little to lose that his case may properly be entrusted to the care of students.

Whether the profession can realistically strive for competent (experienced) trial court representation for all is truly a difficult question. However, no matter how difficult, there is something discouraging and debasing in the image of the profession throwing up its hands and saying that there will never be enough competent (experienced) lawyers, and therefore law students should be allowed to do what they can. It is not as discouraging to prohibit law students from appearing before the bar, despite our fear that we "simply cannot afford" to provide experienced representation for all who need it. If Professor Monaghan's view were followed, each appointment of a

10 Monaghan, supra note 7, at 460-61. One definition of competence set forth by the Survey of the Legal Profession's Committee of Experts on Legal Aid in Criminal Cases suggests a comprehensive standard:

The competency of representation includes competency in advice, in the general knowledge of criminal procedure, in the ability to understand human relationships and an insight into everyday living that can separate sham from truth. Competency means, as well, adequate examination at the preliminary hearing, astuteness in discovering inaccuracy and faulty memory, in recognizing overuse of imagination and downright dishonesty. Competency should also include a full understanding of trial technique, of cross examination [sic] and presentation before a jury. These concepts combined with a fertile knowledge of the law and a freedom to respectfully present objections and counsel's views, all add up to what competency and adequate representation should be.

Quoted in E. Brownell, Legal Atd in the Uivited States 142 (1951).

11 See Monaghan, supra note 7, at 461.

$12 I d$.

13 Several of the Prison Research Council's cases involve men who treated an early charge lightly and bargained for a light sentence, only later to be confronted with increased liability based on such habitual offender statutes. See e.g., N.Y. PENAL LAw \&70.10 (McKinney 1967) (defining a habitual offender as one who has been convicted of two or more felonies and authorizing life imprisonment for the third conviction). 
student to represent a client at trial would provide the client with counsel of virtually no experience. If student representation were barred, on the other hand, clients who would otherwise have been represented by students would, as the profession recognizes its duty in this connection, be represented by qualified attorneys with at least some experience. The Bar should be forced to come to grips with the problem of providing competent representation for all, regardless of ability to pay-an objective toward which significant first steps have been taken recently. ${ }^{14}$ "Student soldiers" should not let their willingness to enter the fray provide a way out for the more reluctant, but professionally, ethically and morally responsible legal warriors-the professional practitioners. In view of this situation, it is ironic that while inexperienced students are cutting their teeth in court at the risk of someone else's liberty, property, and future life-style, they could be functioning quite adequately in an area in which they do have competence, an area in which virtually no nonstudent legal assistance is available to those in need-counselling prison inmates or similarly deprived groups (e.g., state mental hospital patients) on questions of law.

Thus, the Prison Research Council feels that trial work is not, nor will it be, within its proper sphere. The Council has not reached a decision on the possibility of advocacy on briefs or on habeas corpus petitions before the appropriate tribunal. Here the necessary skills (comparison of the merits of differing legal analyses of an agreed fact situation, and advocacy under questioning) are nurtured within the daily activity of the law school. The problem of sufficiently close faculty supervision might raise difficulties, but there is no inherent reason why law students should not become involved in such activity where no constitutional right to counsel exists. The Council may shortly approach the courts for permission to test a program of this nature.

\section{Prisoners: The Most Suitable Clients}

A large number of prisoners have legal questions. ${ }^{15}$ They are unsure of the nature and dimension of their problems, of whether or

14 E.g., the Baltimore firm of Piper \& Marbury has recently decided to open a branch office staffed with full-time firm lawyers, in an area whose residents would otherwise not have access to the legal assistance they need. In Los Angeles, the Wyman-Kuchel firm has reached a similar decision. TIME, April 18, 1969, at 77. In Washington, D.C., the firm of Covington \& Burling will shortly supply 2 associates to work full time in the Neighborhood Legal Services Program.

15 Professor Curtis R. Reitz, the Council Advisor, stated:

One of the sad things about our criminal process is that a lot of men are hurried through and convicted and find themselves in prison without really knowing what happened to them. It helps if we make the prisoner realize that he was treated no differently than others.

Nazarro, supra note 4, at 9, col. 2. 
in what manner counsel could be of assistance, or of how to secure counsel if their cases seem to merit legal action. The fact that prisoners have only limited access to the outside world, that, on the surface, their situations are often unappealing, and that they fail to understand why their numerous appeals to appointed lawyers and petitions to various courts are so uniformly unfruitful, exacerbate the problem. Since it is unfair and unrealistic to expect appointed trial counsel to follow a prisoner's entire career and settle the many questions that can arise after the conviction has been thoroughly litigated, law students can serve the profession and the courts by providing services such as those performed by the Prison Researcl Council. The range of skills needed by student participants mainly includes those which become familiar early in the law school experience: large amounts of library research, memorandum writing, analysis and criticism of one's own writing and that of others. Given time and proper faculty assistance, a professionally competent opinion letter is clearly within the reach of many, if not all, students. Furthermore, the drain on faculty resources is less severe than it might be when faculty members must prepare a student to try a case in court.

The expansion of the Community Legal Services program is making available to people who have civil law problems the same access to counsel which Gideon and its progeny have brought to those confronted by actual and potential prosecution. The desirability and practicality of bringing competent legal help to the entire community becomes more clear daily. Students who counsel prisoners provide a service which they are educationally qualified to provide, to a group which has, for the most part, lacked any counsel in the past. ${ }^{16}$ Not the least of the social values to which the Prison Research Council is oriented is the easing of a prisoner's adjustment through a clarification of the legal process as it has been applied to him. Clarification removes festering doubts in many cases and may help set a man's sights on rehabilitation rather than revenge.

\section{Law School Clinic or a Community Agency Adjunct?}

There are two basic types of law school legal aid clinics: (1) those operated solely by the law school and providing direct service to clients, and (2) those which cooperate with an established legal aid agency and in which the students work under the direction of the agency's practicing lawyers, who are usually unaffiliated with the

16 The Philadelphia Voluntary Defender Association has a program of periodic counseling visits to the many penal institutions in the metropolitan area; however the number of areas in which a sufficient concentration of institutions makes such a program feasible is obviously quite limited. 
school. ${ }^{17}$ In the latter, students essentially operate as law clerks to the practicing attorneys. In the former, students operate more as practicing attorneys than as clerks, although their work is limited to what they can do well, and they are always under the ultimate guidance of a faculty member or other member of the bar. ${ }^{18}$

Several benefits to both students and their clients flow from a school-affiliated, rather than agency-affiliated, status. Perhaps the most significant characteristic of the student in the legal aid clinic is his idealism and his lack of contact with reality (which is a merit, not a demerit, in the clinic context). His classroom life is substantially concerned with the law as it ought to be and as it could be. This orientation carries over to his clinic work. He has a concern for the plight of others, an impatience with bureaucracy, and an unwillingness to compromise his view of justice. He has not seen enough cases to become disillusioned, jaded, or "realistic." The experience is new to him and he greets it with enthusiasm. Furthermore, the "social economics" of the situation do not affect his activity. ${ }^{19}$ This may not be the case when the student works for an agency whose lawyers' experience and large caseloads militate strongly against a rose-colored view of justice.

The intense student-faculty contact which the school-based program requires is a second benefit, and operates in two ways. First, the student has an opportunity to observe the thought processes and operating methods of a unique kind of lawyer, the law professor, whose profession requires more of the scholarly overview than the practitioner's pragmatism. The legal scholar takes a greater interest in, and responsibility for, the functioning of the entire system than the practitioner usually does. Moreover, he is in a position to affect a considerable spectrum of judicial and legislative thought through his published scholarship, and his participation in law revision projects and other forums of legal reform. For many prospective lawyers, the experience

${ }^{17}$ At least one clinic operates essentially as a law school activity, although it is funded by the National Defender Project. See Spangenberg, The Roxbury Defender Project, 24 Legal AID Brief Case 247 (1966).

18 Compare student participation in Defender programs:

The advantage to the Defender Offices in having law students participate in their function is quite limited. The law student is there primarily to observe and to learn, and, if an assignment should be given to him, it would still require the supervision and control of an experienced attorney or investigator. Regardless of the ability and desire of the law student, no stage in the defense of a person accused of crime can be completely entrusted to one inexperienced or unknowledged in the law and procedures of criminal defense.

... Thus the contributions of the law student are necessarily limited. Mancuso, Law Students and Defender Offices, 24 Legal AID BRIEF CASE 242, 245 (1966) (emphasis added).

19 Cf. Monaghan, supra note 7, at 460: "We are all familiar with the too common practice of many lawyers hastily preparing the cases of their less affluent clients on the courthouse steps." 
of close work with this type of person is of great value. Additionally, the institution of the clinic facilitates faculty-student interaction in other areas, and serves to enhance the operation of a law school as a community of scholars.

Operation of the clinic from a law school base also affords the advantage of including in the clinic program general research projects unrelated to any particular clinic case. It can encourage legal scholarship, field research, and interdisciplinary inquiries, all of which broaden the student's educational experience and make a positive contribution to the development of information and doctrine in the much neglected area of prison and prisoner law. ${ }^{20}$ The law is instrumental in identifying a man as needing correction; the time is long past for the law to take an interest in what happens when its prescription is carried out. The law school, especially if connected with a university in which other relevant disciplines are represented, is an ideal place for such activity.

The independence of a school-based clinic is another valuable feature. The clinic is not tied to the performance level, funding, schedule, work load, or political problems of a community agency. Students can undertake more responsibility for their activities and set their own standards. Since they are more than just a small part of an established agency, the students take greater pride in their work. Most law students will spend the bulk of their lives confronting the realities of the practitioner's world. A year or so of "practice" in a more idealistic, reflective situation provides a valuable basis for continuing comparison and role evaluation.

\section{Operation of the Prisoner Response Program}

Although many of the prisoners' letters are addressed to the Dean or to various faculty members, the addressee, in order to expedite matters, usually turns them over directly to the Council without seeking permission to do so from the correspondent. ${ }^{21}$ In several hundred situations, no prisoner has objected to the procedure, although there have been occasional refusals to have the Council proceed with the work. The Council's secretary maintains a chronological log of mail received.

20 See text accompanying notes 33-36 infra.

21 Mail addressed to individual faculty may involve cases in which the faculty member has been appointed counsel or in which he retains a personal interest. Some of the faculty make it a practice to turn all of their prisoner mail over to the Council unless a lawyer-client relationship exists; others prefer to deal with prisoner inquiries themselves. In the latter cases, the Council sometimes supplies research assistance where this seems worthwhile.

Prisoners often make direct requests to the library to copy legal materials. If the request is sufficiently clear, the library can locate the material, copy it, and return it directly to the prisoner. If any research or legal judgment is required in order to determine exactly what material is requested, this is supplied by the Council, whereupon the library provides the copying. 
She also makes up a file card, on which basic information concerning the prisoner's status and the research on his case is recorded. An entry is made in a book which categorizes clientele by prison, state and chronological file number.

When the secretary has prepared these basic records, the prisoner's letter is screened by a third-year member of the Council, the Research Coordinator. ${ }^{22}$ The screening serves several purposes. It provides immediate identification of special problems: for example, capital cases, cases involving deadlines, or cases involving minimal research. Screening also identifies cases in which a prisoner has a right to be represented by counsel $;{ }^{23}$ in these cases, the prisoner is encouraged to avail himself of professional assistance. Similarly, the Council declines to become involved where the prisoner already has an attorney.

When the screener has decided how the problem will be handled, he drafts, or selects from a file of model letters, an acknowledgment letter. A prisoner's letter is usually acknowledged within one day of its receipt. ${ }^{24}$ The screener's proposed acknowledgment is checked for appropriateness and is signed by the Chairman of the Council, a thirdyear student. It is then logged out by the secretary, a notation of acknowledgment is made on the file card, and the letter is dispatched. In its initial communication with the prisoner, the Council makes every effort to impress upon him that he is dealing with students, not professors or practicing attorneys. No research is begun until the prisoner understands and accepts the fact that students will handle his problem.

The file is then assigned to a research team. Two third-year Council members are responsible for the workload arriving on a given day of the week. They become substantively familiar with each problem as it comes in, discuss possible approaches to a solution, and assign the problem to a student or students for research. Researchers are students who have completed at least the first semester of law school (in practice, almost all are second-year students). Any member of the

22 The Research Coordinator maintains a cross-indexed reference file of Council memoranda into which he keys relevant citations from incoming advance sheets. Thus he is often able, during the initial screening, to cite material from the research file which helps initiate the research.

23 Approximately $10 \%$ to $15 \%$ of the petitioners have a right to counsel. Nazarro, supra note 4 , at 7 , col. 2 .

24 In cases requiring only minimal research, the research is completed within a day or so, and no acknowledgment is necessary. The Council tries to keep one member on the job at all times, including vacations, to deal with cases in which delay might cause the prisoner to miss an important deadline, e.g., for the filing of an appeal. Deadlines present greater problems as they become more esoteric than merely perfecting an appeal. For example, one state may require notification of a county prosecuting attorney that a prisoner is seeking collateral relief earlier than most others, or in more detail, or in special form. Because of the complexities of various deadlines, Council members and the faculty advisor pay particularly close attention to the problem. 
student body is welcome to stop in at the Council office and be assigned a file for research. The researcher discusses the case with the thirdyear student who has assigned it to him and engages in a few hours of exploratory research. When he feels that he has a suitable research plan, he discusses it with the third-year student again, and possibly with a faculty advisor.

Many of the letters received are nothing more than broad inquiries questioning whether the Council will help solve a legal problem, not clearly defined by the letter. ${ }^{25}$ Because elucidation of all the relevant facts is, of course, a prerequisite to a valid solution of the problem, a questionnaire which elicits the information most frequently found wanting in prisoner letters is often sent to the prisoner, who is informed that the Council must have the detailed answers to the questionnaire before beginning work on the problem. Following submission of his answers, the prisoner is informed that there will be a delay of several weeks, or perhaps months, in researching and answering the problem, depending on the clinic's caseload and the nature of the problem.

When the researcher has finished his memorandum, it is edited by another third-year student. Eventually a final draft of the memorandum, and a draft opinion letter, are prepared. The opinion letter is couched in language which the prisoner is likely to understand; his capacity to do so can usually be estimated by the quality of the letters sent to the Council. The opinion letter and memorandum are submitted to a faculty member for approval. Corrections are made, further research, if necessary, is discussed by the faculty member both with the researcher and with the responsible third-year student, and, ultimately, an acceptable memorandum and letter result. The letter is logged and mailed, ${ }^{26}$ and copies of the memorandum go to the researcher for his files, to the prisoner's file, and to the Council's Research Coordinator.

Whenever possible, opinion letters include copies of the relevant cases or statutes if it appears that this material will be of use to the prisoner either in understanding his situation or in further proceedings. The letters often contain suggestions on how to present petitions for hearings or other remedies to the courts. If a prisoner's case appears

25 Many prisoner letters ask something like "send me the law on narcotics." A standard reply letter or questionnaire form asks for a detailed description for 2 reasons. First, it is necessary to have all relevant facts before research can be begun. Second, the Council wants to be sure that a prisoner is requesting help in a situation that involves him personally. It does not want to become a staff of research consultants to jailhouse lawyers seeking to expand their practice. The questionnaire is designed to reveal such situations. For a description of the questionnaire, see Nazarro, supra note 4 , at 6 , col. 3 .

26 Opinion letters go out in the name of the Prison Research Council, per the student chairman, largely to protect individual students from either undue popularity or opprobrium at the hands of the grapevine, and also to stress the commitment to group research, analysis and editing. 
to have merit, and the services of a local attorney are needed, the Council attempts to help the prisoner locate one, either through the appropriate local bar association, or through a University of Pennsylvania alumnus in the area in which help is needed. ${ }^{27}$ The Council also discusses cases with prison officials, parole and probation officers, and judges when appropriate.

Whenever a prisoner appears to be questioning the sufficiency of the evidence, ${ }^{28}$ he is informed that the sufficiency is determined only once, with limited review in an appellate court. If the appeal has not been exhausted and the deadline for filing has not passed, he is informed of his right to counsel on appeal. ${ }^{28}$ Where an appeal is not possible, he is told that the sufficiency of the evidence cannot be relitigated. ${ }^{30}$ To tell a prisoner that he has no legal recourse open to him is done, because of the authorative nature of its finality, only with reluctance and after careful investigation. ${ }^{31}$

27 Philadelphia area cases are usually turned over to the local Voluntary Defender Office. Through a program in Criminal Law and Litigation, a course in which students do interviewing, screening and research in connection with the Philadelphia Voluntary Defender program, 2 Prison Research Council students have been able to work on Council cases during their preparation for court hearings. One of these cases, a petition for relief under Pennsylvania's Post Conviction Relief Act, was recently won largely due to the brief of the Council member to whom the case was initially assigned. A second will shortly be argued in the Pennsylvania Supreme Court; again, the brief will largely be the work of the student who was originally assigned the Prison Research Council file.

28 Although most letters are vague, problems involving the sufficiency of the evidence can often be screened out quickly. A typical example is:

\section{Prison Research Council:}

April 15, 1969

I was convicted of a Philadelphia burglary even though I had a perfect alibi. My brother Robert swore right there in court that I was with him in New York that night. Just because he was a convicted rapist and my fingerprints were on the store window, the jury wouldn't believe my brother's sworn bible oath. How can they be permitted to do this?

Irving Innocent

29 An excerpt from the typical letter reads:

You have a right to be represented by legal counsel on appeal of a conviction. If you cannot afford an attorney, counsel will be provided by the Court. Presumably, this will be the Voluntary Defender. If you have any difficulty contacting a representative of the Defender's Office, and you think we can be of any assistance, please let us know.

30 Although it is done only when there are no alternatives, the Council must at times reply:

The time within which you might have appealed has passed. There is no way for you to retry the matter of your innocence from the standpoint of the sufficiency of the evidence. You are not entitled to relitigation of the basic fact determination.

31 Problems such as sufficiency are compounded when the prisoner has a valid technical ground for reversal, e.g., when he has been denied the right to counsel. Because of the unpredictability of retrial and the possibility of harsher resentencing, the Council is caught on the horns of a dilemma-whether it should advise the client what to do or simply elucidate the various possibilities, leaving the final decision to him. If the prisoner relies on Council advice and receives a stiffer sentence, there 
In some cases, the Council opts to have its faculty advisor handle problems. For example, a prisoner who is approaching eligibility for parole may be justly concerned about a detainer that has been lodged against him. In the event he is paroled, he will have to stand trial for another offense. A practicing attorney, retained by the prisoner, could properly negotiate with the detaining authority to try to resolve the difficulties. He might try to convince the prosecutor to drop the prosecution or in appropriate situations request a speedy state trial provided for federal prisoners by 18 U.S.C. $\$ 4085$ (1964). Because of the problem of determining the standards of performance to which a clinic should be held, ${ }^{32}$ the Council can use the faculty advisor, a practicing lawyer, to advantage. Furthermore, an appeal from him to the responsible individual will probably carry more weight than one from a volunteer group of students.

Any student who substantially contributes to the effectiveness of the Council's program is eligible for membership and students are elected to membership as soon as they demonstrate the requisite competence and interest. Early in the second semester, the present Council members elect a second year student to the Chairmanship, and the other second year members (some newly elected at the time, some elected earlier if their performance merits it) are assigned new roles in the Council's work.

Essential to the smooth operation of the process outlined above is a skillful administrative secretary, who must see to it that the paper moves smoothly through the organization, and that each piece of correspondence is accounted for in the log, card file, and other records. She should also keep the Chairman apprised of any undue delays that come to her attention. A check of the log entries of 30 and 60 days prior to any given date reveals problem situations since most files are dealt with within a month's time. The less time spent by students in doing this routine administrative work, the more time they can spend on their cases.

\section{Nature of the Work}

The Council has now processed over 1,000 requests for assistance. While it is impossible to be precise as to the incidence of various prob-

may be liability on the part of the Council, as discussed later, see text accompanying notes $77-84$ infra. On the other hand, if no probabilities are attached to the possibilities, the prisoner has little basis on which to make his judgment. Without the aid of a lawyer, whom he cannot afford (and who is no longer supplied without cost), he is helpless. Perhaps at some point the clinic itself ought to seek advice from a practitioner experienced in the forum in question. If the facts are sufficiently refined and the question is concisely presented, the practicing lawyer could probably come to a judgment without being unduly burdened.

32 Part II, infra, discussess possible standards for the student participant in a legal aid clinic. 
lems, a significant number of cases have involved detainer problems, sentencing procedure and sentence computation, ${ }^{33}$ search and seizure, confessions, and plea bargaining. In addition, there is a category best described as "how-can-they-do-this-to-me?" This type of question is by far the most frequent, which largely explains the fact that of the files handled thus far, only two outright releases of improperly incarcerated prisoners have been obtained by Council effort alone. ${ }^{34}$ In most cases brought to the Council's attention, the likelihood that reversible error has been committed is slight, though most prisoners seem to feel that any error, however slight, should lead to immediate and irrevocable freedom. In these situations, a patient explanation that "yes, they can do it to you, and here's how and why" amounts to one of the finest services the Council can provide. On the one hand, the Council can remove a festering conviction that manifest injustice has been perpetrated. It can, at least, provide an adequate, understandable view of the system's position and functioning in each individual's case. ${ }^{35}$ On the other hand, the Council can identify areas of the law which on the surface seem quiet, but which, as complaints increase, are clearly seen to be troublesome.

The law moves slowly where prisons and prisoners are concerned, and serious problems exist at many levels: what effect do detainers have on a man's chances for parole? How do they affect his morale, and the likelihood of his rehabilitation? What are the proper bounds of parole board discretion? What does the civil rights movement have in store for prison administration? What rights does a prisoner retain despite his imprisonment? What are the requisites of effective assistance of counsel ? ${ }^{36}$ In a seminar given by one of its faculty advisors,

33 In the only 2 cases to date in which release of prisoners has been obtained through Council efforts, improper sentencing was the nexus of the case. See Schultz v. United States, 384 F.2d 374 (5th Cir. 1967). The second prisoner was released following a petition under the Pennsylvania post-conviction hearing act in the fall of 1967 . There is no reported decision. See note 27 supra.

$34 \mathrm{It}$ is impossible to estimate the number of prisoners who have gained their freedom with some help from the Prison Research Council. In right-to-counsel cases, for example, once an attorney is found for the prisoner, the Council's work is done, and it often loses track of the case. Nazarro, supra note 4, at 7, col. 3.

35 As the 1968-1969 Chairman of the Council stated:

We are not out to tear down the walls; we are not crusaders; we are not "Judd for the Defense." But once in a while we do help a prisoner win a new trial, or cut his sentence because of some technicality or error. It's impossible to say how many may be innocent-they all say they are innocent-but I'd estimate that perhaps four percent of the cases we've seen involve something questionable.

Id. 7 , col. 1.

${ }^{36}$ This is one of the most vexing problems. The Council, although it scrupulously avoids involvement with prisoners who are represented by counsel, realizes that a certain proportion of clients will have received inadequate representation at the hands of their court-appointed attorneys. The Council is studying how to be more effective in helping those who may have been victimized by ineffective counsel, but, as suggested earlier, the solution does not seem to be substitution of law students for lawyers. 
Council members and other interested third-year students may satisfy their senior writing requirement by doing research in these areas. As an added incentive the Council offers its forthcoming Prison Research Monograph series as a forum for publication of the best of this work. The Council hopes, thereby, to make a contribution to a more intelligent, effective, and legally acceptable penology. A constant influx of prisoner letters is an excellent means of identification of the problem areas, and work is under way in those areas described above, among others. Thus the Council attempts to offer something for every law student who seeks to extend his educational experience, and does so in an area in which attention is sorely needed, but is not likely to be forthcoming to a satisfactory extent from other sources.

\section{E. Support for Clinic Activities}

Administrative secretaries, stationery, office space, office equipment and supplies, postage, printing of monographs, travel and other activities incidental to research all require money. Depending on the school's ability to provide support, supplementary funds may be required. The Prison Research Council first operated on a two-year budget which drew on grants from the Council on Education in Professional Responsibility of the Association of American Law Schools, and from the William H. Donner Foundation, a private foundation. These sources were discovered after investigation of, and correspondence with, various potential sources known to the faculty and other university agencies. The bulk of the Council's expenditures were for office space and equipment and for secretarial assistance. Publication of monographs will also require substantial funds. The budget, a relatively small $\$ 17,000$ for the first two years, has increased to approximately $\$ 10,000$ for the third year. The Council feels, from its own experience, that a wellconceived project will not have difficulty finding support in amounts of this size, should school office space and secretarial help not be available. In the Council's case, it ran on a $\$ 50$ shoestring, provided by the school, for the better part of a year before it sought funds; it could therefore "point with pride" to a record of achievement. Such a trial period is undoubtedly worthwhile in determining whether full-scale commitment to a clinic project is desirable.

Identification of legal problem areas, assistance to people in need of legal assistance, establishment of relationships with, and increased understanding of the problems of attorneys, professors, prosecutors, defenders, and penologists are all valid aims of a professional education. Law school legal aid clinics are excellent vehicles by which such aims may begin to be fulfilled. 


\section{Legal Status of School-Based Clinics}

Because students in school-based agencies have primary responsibility for managing the entire agency program, their activities resemble those of a small law firm. This is especially true when the students' competence is high, in which case the role of faculty guidance becomes more the review of a professionally satisfactory end product than step-by-step direction.

The fact that the student working in a school-based agency does not receive a carefully parcelled-out assignment from a "real" attorney, who actively oversees his work and who has the "real" responsibility for the case, imposes a considerable burden of responsibility upon the student himself. In such activity, is the point reached at which so much responsibility is assumed that the students are in effect practicing law? If so, is there any reason why, in these limited circumstances, they should not? If the latter question is answered in the negative, should students who practice law be liable to suit for malpractice? By what standard should their work be judged? Articulation and analysis of such problems is a sine qua non of any effort to encourage the development of school-based clinics both as vehicles for social service and as opportunities to provide experiential education in professional responsibility.

\section{A. Are the Students Practicing Law?}

Two rationales might be offered to support a contention that law school clinics do not become involved in the practice of law-the law clerk theory and the lay-advocacy model-but neither is persuasive. It is instructive, however, to analyze them in order to gain insights into the problems of setting standards of ethics and competence for schoolbased clinics.

In the community-based (as compared to the school-based) agencies, the students may be viewed simply as law clerks to supervising attorneys. The attraction of extending this doctrine by analogy to say that students in school-based agencies are simply law clerks to guiding faculty members, rather than practitioners of law is apparent. ${ }^{37}$ The kinds of activities described earlier in this article, ${ }^{38}$ however, are not normally understood to be in the proper domain of law clerks.

As one court has defined the law clerk's proper role,

[T] he nature of their work approaches in a degree that of their employers. The line of demarcation as to where their work begins and where it ends cannot always be drawn with absolute distinction or accuracy. Probably as nearly as it can be fixed .. . [the law clerk's work] is work of a 
preparatory nature, such as research, investigation of details, the assemblage of data and other necessary information, and such other work as will assist the employing attorney in carrying the matter to a completed product, either by his personal examination and approval thereof or by additional effort on his part. The work must be such, however, as loses its separate identity and becomes either the product, or part of the product, of the attorney himself. . . . [In the instant case, the work of the clerk in question] had its own personality and bore the same stamp of skill and ingenuity as though rendered by an attorney. ${ }^{39}$

Legal aid clinics which function in their own names, have their own offices, stationery and funds, and whose students may interview and correspond directly with clients, judges, prosecuting attorneys, parole boards, social workers, law professors, and others, simply are not conducting activities which become part of the work product of the guiding faculty members. ${ }^{40}$ The benefits of learning to assume professional responsibility, as distinguished from the benefits of polishing research and writing skills, accrue in direct proportion to the extent to which such merging does not take place. The best student legal aid clinic, from the student's point of view, is the one in which student members are much more than faculty research assistants; it is a small law firm, in which senior students are partners, less experienced students are associates, and faculty are "of counsel."

The second rationale which might be offered in support of a contention that students in clinics do not practice law has best been expressed by $\mathrm{Mr}$. Justice Douglas in his vigorous opinions in Hackin $v$. Arizona $^{41}$ and Johnson v. Avery. ${ }^{42}$ This approach will be called the

39 Ferris v. Snively, 172 Wash. 167, 19 P.2d 942 (1933). Plaintiff was a law clerk seeking to recover from the executor of his preceptor's estate, payment for services rendered to various clients of his preceptor both before and after the preceptor's death. The executor raised the defense that the work, which consisted of "examining abstracts, preparing wills, handling matters in justice courts, and looking after uncontested probate matters" was authorized to be done only by a licensed, practicing attorney, and that plaintiff could not, therefore, assert a right to payment. (The equity "clean hands" doctrine was doubtless in the executor's mind.) The court held that plaintiff's activities indeed constituted the unauthorized practice of law, but that while such unauthorized practice might be a valid defense to a money claim by the clerk if invoked by a client, it was not valid as raised by preceptor's executor. Id. at 176, 19 P.2d at 945 .

40 But see Monaghan, supra note 7 , at $457-58$.

41389 U.S. 143 (1967) (per curiam) (Douglas, J, dissenting), denying cert, to Hackin v. State, 102 Ariz. 218, 427 P.2d 910 (1967).

In Hackin the Court dismissed defendant's appeal of a conviction under an Arizona law making it a misdemeanor to practice law without, inter alia, having been admitted to the state bar. Hackin was a graduate of an unaccredited law school, and was therefore ineligible to take the Arizona Bar Examination. Hackin v. Lockwood, 361 F.2d 499, 500 (9th Cir.), cert. denied, 385 U.S. 960 (1966). Nevertheless, he prepared and argued a habeas corpus petition for an indigent prisoner, before the court discovered that he was not a member of the bar. Convicted of a misdemeanor, Hackin appealed to the state supreme court, which affirmed the conviction. Hackin v. State, 
"lay advocacy model." Justice Douglas, motivated by the inadequacy and seeming inability of the present system to make qualified legal assistance available to everyone, discusses some of the "new and

102 Ariz. 218, 427 P.2d 910 (1967). On appeal to the United States Supreme Court, he argued that the statute suffered from "overbreadth and vagueness and is unconstitutional on its face because it interferes with the rights of the destitute and ignorantthose who cannot acquire services of counsel-to obtain redress under the law for wrongs done to them." 389 U.S. at 144 (Douglas, J., dissenting).

In the habeas corpus situation, it was traditionally possible, for obvious reasons of necessity, for individuals other than the detainee to institute proceedings designed to call the court's attention to problems of improper detention. A "next friend" could institute the proceeding if he could show an appropriate interest and a good reason why the detained person himself did not institute the action. United States ex rel. Bryant v. Houston, 273 F. 915, 916-17 (2d Cir. 1921).

The courts typically offer considerable protection to third parties offering assistance in getting habeas corpus petitions before them:

[I]t is apparent that without the assistance of some third party, many prisoners in the state penitentiary would be totally incapable of preparing an intelligible petition, letter or request on their own behalf ... [T] incapacities (sub-standard intelligence, inability to write, etc.) which make it impossible for a prisoner to draft a meaningful habeas corpus petition also make it impossible for him to draft a letter which would be sufficient to arouse the attorney's interest. Furthermore, few indeed would be the lawyers who would volunteer to represent such prisoners, the great majority of whom are totally indigent.

Johnson v. Avery, 252 F. Supp. 783, 784 (M.D. Tenn. 1966), rev'd, 382 F.2d 353 (6th Cir. 1968), rev'd, 393 U.S. 483 (1969).

42393 U.S. 483 (1969).

In the Johnson case a prisoner filed a "motion for law books and a typewriter" after falling afoul of prison regulations barring prisoner writ-writers from pursuing their jailhouse practices. The district court treated Johnson's motion as a petition for habeas corpus, and the motion was granted. The Sixth Circuit reversed, 382 F.2d 353 (6th Cir. 1968), and was itself reversed by the Supreme Court. Writing for the Court, Mr. Justice Fortas based his opinion on the unavailability of any alternative for the "high percentage of [inmates] who are totally or functionally illiterate, whose educational attainments are slight, and whose intelligence is limited." 393 U.S. at 487 (footnote omitted). In a concurring opinion, Mr. Justice Douglas seized the opportunity to express substantially the same sentiments as appear in his Hackin dissent. Since the legal contexts of the 2 cases differ, however, the Johnson opinion does not stand for the proposition that writ-writing by well-meaning lay assistants cannot be punished as the unauthorized practice of law, despite Justice Douglas's conviction that "[1]aymen-in and out of prison-should be allowed to act as 'next friend" to any person in the preparation of any paper or document or claim, so long as he does not hold himself out as practicing law or as being a member of the Bar." 393 U.S. at 498. As will shortly be pointed out, this statement ignores the very troublesome problems of ethical standards and the practitioner's liability for negligence, which are answered by placing such activities in the professional context, rather than out of it. In this author's opinion the emphasis should properly be on the profession's creation of effective alternatives to lay representation, rather than on throwing the doors open to well-meaning but unregulated "next friends."

Furthermore, the courts understand the purpose of the "next friend" doctrine as enabling an otherwise inept person to come to the attention of the court. Once he is before the court, the complainant is required to substitute a lawyer for his next friend. It is doubtful, for example, that Hackin would have been prosecuted had he merely prepared a written petition. However, in failing to call attention to his unlicensed status, he both misled the court and deprived the indigent of an opportunity to be represented by licensed counsel. Part II, infra, argues that the "next friend" justification of legal aid clinics stops when clinic activity is of the type normally cognizable by the court in the unauthorized practice of law context. Johnson makes no provision for lay representation in court or before parole boards. It should be viewed as providing last-ditch relief in cases of extreme deprivation, rather than creating or legitimizing an entire subclass of lay-advocates, as Mr. Justice Douglas would wish. 389 U.S. at 144 (Douglas, J., dissenting). 
flexible approaches" characterized by neighborhood legal offices, which use "lawyers, social workers, members of health professions and other nonlawyer aides." 43 He mentions the "necessary involvement of lay persons" 44 which results from the fact that "the problems of indigentsalthough of the type for which an attorney has traditionally been consulted-are too immense to be solved solely by members of the bar. The supply of lawyer manpower is not nearly large enough." 45 Justice Douglas reiterates a criticism made previously by Edgar and Jean Cahn:

[W] have created an artificial shortage by refusing to learn from the medical and other professions and to develop technicians, nonprofessionals and lawyer-aides-manpower rolls to carry out such functions as: informal advocate, technician, counsellor, sympathetic listener, investigator, researcher, form writer, etc. . . . [T] he possibility of advancing the cause of justice through increasing lay involvement in fact finding, adjudication and arbitration, should not be sacrificed a priori out of a fear of abuse. ${ }^{46}$

Law students are already put to use in at least some of these capacities in OEO-funded legal services programs, ${ }^{47}$ but the analytical rationale, as distinct from a recitation of the need, for the use of lay people to provide what have traditionally been considered professional legal services remains to be articulated; in Hackin and Johnson Mr. Justice Douglas succeeds at the former but does not attempt the latter. One of the serious problems of proceeding along such an uncharted course is the failure even to consider, let alone to determine, the standards of ethics and "professional" responsibility to which lay personnel should be held. At present either the ethics of these people are controlled by nothing but their own sense of integrity, or they are subject to the same ethical standards as the lawyers who supervise them. ${ }^{48}$ No other standard seems to exist. Because of the difficulty in delineating lay advocacy from law practice, most courts would probably be prone to view such use of laymen as falling within the

$43 \mathrm{Id}$, at 146 (footnote omitted).

44 Id. at 147. See also 393 U.S. at 498.

$45 I d$. (footnote omitted). See also 393 U.S. at 493.

46389 U.S. at 147 n.5 (quoting Cahn \& Cahn, What Price Justice: The Civilian Perspective Revisited, 41 Notre DAME LAw. 927 (1966)).

47 Id. at 147 n.4.

48 See Application of Community Action for Legal Services, 26 App. Div. 2d 354, 274 N.Y.S. 2d 779 (1st Dep't 1966), in which permission was denied 3 corporations to practice law because the court was concerned that large agencies could not maintain the minimal supervision necessary to retain high standards. The court stated that only lawyers were to have the power to hire, fire and control money, and that guidelines must be articulated for laymen to follow (whether or not law students are laymen is not clear). 
"law clerk" concept, which is relatively familiar to them. A preferable alternative, at least in the case of law school clinics, is to recognize that the "lay" practitioners are more akin to lawyers than to laymen, and to treat them, to the limits of their capabilities, as lawyers. ${ }^{49}$ This theory is the basis for the court rulings, to be discussed shortly, authorizing certain groups of law students, in suitably supervised programs, to practice.

Ultimately, one must come to grips with the fact that this is precisely what the students are doing. While plotting the "line of demarcation, often shadowy and wavering, which defines the limits of the functions of the legal adviser from those of the layman," 50 is difficult, courts usually use three factors ${ }^{51}$ to test whether activity constitutes "practicing law": compensation, complexity of the problems handled, and the use of legal skill or knowledge.

The notion that certain activities constitute the practice of law simply because compensation is demanded suggests that the complaining lawyer or bar association ${ }^{52}$ may be more interested in protecting a source of livelihood than in protecting the public from the unscrupulous unathorized practitioner who offers inferior legal services. However, a fair number of cases have adopted reasoning to the effect that "if compensation is exacted, 'all advice to clients and all action taken for them in matters connected with the law are practicing law'," ${ }^{53}$ while " $[t]$ he occasional drafting of simple deeds and other legal instruments when not conducted as an occupation or yielding substantial income may fall outside the practice of the law." "54 Other courts have rejected this theory, arguing that reliance by the client on advice or services rendered is more important than whether or not compensation

49 See text accompanying notes 57-63 infra.

50 State ex rel. Johnson v. Childe, 139 Neb. 91, 95, 295 N.W. 381, 384 (1941) (layman appeared before state railway commission; prepared and filed pleadings, examined and cross-examined witnesses, made objections during testimony, advocated his client's position; held not to be unauthorized practice of law, absent a showing that legal training, knowledge and skill were required to perform these functions), cited in AMrerican Bar Foundation, Unauthorized Practice Source Book 68 (rev. ed. S. Bass ed. 1965) [hereinafter cited as Source Book]. See also Source Book 68-69.

51 These 3 factors are suggested in Source Book 67-82.

52 Even the most casual observation of the existing case law and literature (of which the best single source is SourCE Book) reveals that the anti-unauthorized practice campaign is almost exclusively conducted by the organized bar or by individual attorneys as complainants.

53 Fitchette v. Taylor, 191 Minn. 582, 584, 254 N.W. 910, 911 (1934) (layman adjuster furnished opinion on right to maintain action against others; drew contracts, releases and affidavits for others; furnished advice regarding liability and amount of damages; solicited, settled and adjusted personal injury claims; interviewed witnesses; and advocated with insurance companies and other parties, all for compensation; held: unauthorized practice).

54 Opinion of the Justices, 289 Mass. 607, 615, 194 N.E. 313,317 (1935) ; see also cases cited in Source BooK 78-79. 
is exacted. ${ }^{55}$ One court stated that "the weight of authority, where such issue has been presented, is that the character of the service and its relation to the public interest, determines its classification,- - not whether compensation be charged therefor." 56

While enlightened courts reject the compensation notion as definitive, for present purposes, the merits of the question need not be resolved. In most school-based situations no money changes hands, and normally there is significant public service motivation for the student activities. Yet one undeniably substantial component of student motivation is the benefit, described earlier, accruing to student volunteers. No court following the compensation theory appears to adopt the reasoning that since the client gave nothing he should expect nothing. A "compensation theory" court might well hold, therefore, that a profit motive exists even in a school-based clinic. The compensation theory does not seem to yield a satisfactory answer to the question of the practice of law vel non.

Analysis of the complexity of the problems handled has been used to gauge whether or not performance of certain services is the practice of law, on the theory that some matters are so simple as to require only a layman's skill, and no special training. ${ }^{57}$ This analysis has also aided some courts in drawing lines between the practice of tax accounting and tax law, ${ }^{58}$ and between legal conveyancing and routine real estate transactions. ${ }^{59}$ However, this theory has been rejected by other courts which feel that the decision properly turns on whether legal judgment is used-in selecting the proper realtor's form and understanding its effect, for example-rather than on whether the form is simple or complex. ${ }^{60}$

Deciding whether the complexity test may or may not be a valid means of resolving unauthorized practice questions in other contexts is neither necessary nor helpful here. The greater the complexity of the problem which confronts the student, the greater are the benefits

55 E.g., Arizona State Bar v. Arizona Land Title \& Trust Co., 90 Ariz. 76, 366 P.2d 1 (19661), supplemented, 91 Ariz. 293, 371 P.2d 1020 (1962) (layman prepared, drafted and formulated documents affecting title to real property, and gave advice regarding the documents and the transactions in which they were involved; held: unauthorized practice), cited in SoURCE Book 78.

56 Grievance Committee of State Bar v. Dean, 190 S.W.2d 126, 129. (Tex. Civ. App. 1945) (layman wrote wills, did conveyancing, and rendered opinions on title to real property; held: unauthorized practice).

57 See generally cases cited in Source Book 80-81.

58 See In re Bercu, 273 App. Div. 524, 78 N.Y.S.2d 209 (1st Dept. 1948), aff'd. without opinion, 299 N.Y. 728, 87 N.E.2d 451 (1949); Gardner v. Conway, 234 Minn. 468, 48 N.W.2d 788 (1951).

59 See Hulse v. Criger, 363 Mo. 26, 247 S.W.2d 855 (1952), cited in Source Book 81, for the proposition that "fflling in blanks of a form deed requires only ordinary intelligence."

60 See, e.g., Pioneer Title Ins. \& Trust Co. v. State Bar, 74 Nev. 186, 326 P.2d 408 (1958). See also Source Book 80-83. 
he reaps through solving it. School-based clinics do not limit their offer of help to clients whose problems are simple. The students welcome highly complex work and they get it. Many of the problems submitted to the Prison Research Council involve questions of federalstate relationships, multiple prosecutions, sentence computations, multiple probations and parole violations with attendant detainers. These problems require considerable ability to deal with interlocking statutes, administrative law problems, conflicts problems, evidence problems, and so forth. Insofar as the complexity test may constitute a valid approach to the problem, school-based clinic work doubtless involves the practice of law under this test.

Several courts have applied a third test based on the use of legal skill and knowledge. ${ }^{61}$ This test states that if a client comes to a practitioner for services that he knows will require legal skill or knowledge, and if such legal skill or knowledge is actually or purportedly used by the practitioner and relied upon by the client in conducting his affairs, the practice of law is involved. These are clearly the terms upon which clients approach school-based clinics. Under this test there seems to be no valid distinction among (1) performing straightforward legal research and writing in an effort only to "find the law" and report it, (2) discussing the alternatives available to a client based on the results of such research and writing, and (3) advising or counseling the client concerning the most desirable course of action. All of these are activities which lawyers are commonly understood to do, ${ }^{62}$ and for which, in the normal course of events, one would

61 E.g., In re Mathews, 58 Idaho 772, 79 P.2d 535 (1938) (layman provided abstract, insurance, form deeds, mortgages, contracts, leases, and bills of sale; he simply filled in blanks and did not shape instruments from masses of facts which would require a trained legal mind; held: mere acts of a scrivener, and not the practice of law); People ex rel. Illinois State Bar Ass'n v. Schafer, 404 Ill. 45, 87 N.E.2d 773 (1949) (layman prepared deeds, contracts, mortgages, and advised substitution of his work for preparation of a will by an attorney; held: guilty of unauthorized practice); People v. People's Stock Yards State Bank, 344 Ill. 462, 176 N.E. 901 (1931) (bank acted as executor and trustee and collected the fees customarily allowed by probate court for lawyers who performed these services; the bank also engaged in foreclosure, purchase and sale of real estate, including preparation of abstracts and title insurance, mortgages, trust deed, representation in sales negotiations, tax rent adjustments, etc.; the bank further supervised drafting of deeds containing covenants, easements and building agreements; held: unauthorized practice of law); Fink v. Peden, 214 Ind. 584, 17 N.E.2d 95 (1938) (adjuster negotiated settlement with railroad on claim for death of deceased employee on behalf of his widow and children; held: practice of law); Johnson v. Childe, 139 Neb. 91, 295 N.W. 381 (1941), discussed in note 50 supra.

$62 \mathrm{~A}$ series of decisions involve the question-begging notion that the practice of law may be defined simply as what is "commonly understood" to be the practice of law. E.g., People v. Lawyers Title Corp., 282 N.Y. 513, 519, 27 N.E.2d 30, 33 (1940) and cases cited in Source Book 67-68. What lawyers are "commonly understood" to do is inadequate by itself as a test; it is, however, germane to the issue of whether or not there has been reliance on a non-lawyer for services which normally would be secured by consulting a lawyer. Diversion from lawyers to non-lawyers of reliance for legal advice appears to be the gravamen of the unauthorized practice problem. See text accompanying notes 37-49 supra. 
and should rely upon a lawyer. Therefore, the individual to whom the client turns, if he holds himself out as willing and able to perform such services, and if he renders services which the client is told or led to believe are reliable, is a practitioner of law. ${ }^{63}$

Regardless of which, if any, of the three factors is used, it is highly probable, therefore, that students participating in the work of clinics will be considered to be practicing law. The law clerk argument fails for the reasons stated earlier, ${ }^{64}$ while the arguments against accepting the "lay advocate" theory in the clinic context are powerful. When law students graduate, pass the bar examination, and are admitted to practice, they will be bound by the ethical standards of the bar. The "lay advocacy" concept, at its present stage of development, does not suitably respond to the indigent client's perfectly proper questions regarding his practitioner's standards of ethics and responsibility. Certainly when a constitutional right to counsel exists, any substantial diminution of such standards would so diminish the quality and basic nature of representation that "lay advocacy" would not measure up to the constitutional "effective assistance" standard. On the other hand, putting school-based clinics on a "practicing law" basis provides an accessible standard of professional responsibility. The student is held to the same ethical standard as is a member of the bar; the standard of competence would, of course, be appropriately modified to acknowledge student inexperience (which the client, of course, has initially acknowledged). While practitioners in other areas of assistance to indigents may agree that in their frames of reference the "lay practitioner" approach is valid, it is distinctly inappropriate for law students to seek to avoid the standards of professional ethics and responsibility during their school years, while gaining the benefits of clinic practice.

\section{B. School-Based Clinics and the Unauthorized Practice Issue}

From the analysis in the previous section it seems not only likely, but desirable, that the law students who work for law school-based clinics will be considered to be practicing law and, therefore, be bound by the lawyer's canons of ethics and standard of conduct. The issue then arises whether this law practice is legal, i.e., authorized, or how it can be made so.

Despite the earlier allusion to development of unauthorized practice complaints in order to protect lawyer's livelihoods, it is obvious that some very reasonable public policy arguments are at the base of

63 See Annot., 13 A.L.R.3d 1132, 1139 (1967), for cases in which an unlicensed law clerk who performed tasks requiring legal knowledge or skill was held to have engaged in the unauthorized practice of law.

64 Text accompanying notes $37-40$ supra. 
the effort to eliminate unauthorized practice. Rejecting the notion that the movement against unauthorized practice is motivated primarily by the selfishness of the organized bar, one writer asserts:

Actually, unauthorized practice of law is a swindle upon the public. Whenever it takes place, some person receives either incompetent or unqualified advice, or advice which cannot be honestly disinterested. Such advice, in many instances, can deprive the person so advised of protections to which the law entitles him. Reliance upon such advice may result in irreparable injury and loss. ${ }^{65}$

The dangers of unauthorized practice by law students ${ }^{68}$ have been articulated as follows:

[A]ny law student . . . is apt to overlook relevant facts, to base his opinion of the law on a century-old case in a minority jurisdiction, to be unaware of statutory or administrative regulation which has supplanted the common law, and to fail to recognize the available defenses. Because the law is, in fact, a "seamless web," it is impossible to give competent advice in one area without a partial understanding of all the law. ${ }^{67}$

Compare this assessment of student performance with the requirements for competency quoted earlier:

The competency of representation includes competency in advice, in the general knowledge of criminal procedure, in the ability to understand human relationships and in insight into everyday living that can separate sham from truth. Competency means, as well, adequate examination at the pretrial hearing, astuteness in discovering inaccuracy and faulty memory, in recognizing overuse of imagination and downright dishonesty. Competency should also include a full understanding of trial technique, of cross examination [sic] and presentation before a jury. These concepts combined with a fertile knowledge of the law and a freedom to respectfully present objections and counsel's views all add up to what competency and adequate representation should be. ${ }^{68}$

One writer asks "How many practicing attorneys, let alone law students, can measure up to what appears to be such a reasonable

65 E. Otrerbourg, A Study of Unauthorized Practice of the Law 5 (1951), quoted in E. Cheathani, Cases and Matrrials on THE Legal Profession 463 (2d ed. 1955); accord, In re Baker, 8 N.J. 321, 328, 85 A.2d 505, 514 (1951).

66 The context is a law student, home on vacation, called upon for advice by a friend or member of the family.

or Comment, Unauthorized Practice by Lawe Students: Some Legal Advice About Legal Advice, 36 Tex. L. REv. 346, 348 (1958). But see Monaghan, supra note 7, at $460-61$.

68 Quoted in E. Browneld, Legal Am in the United States 142 (1951). 
standard ?" 69 It should be noted that most of the factors mentioned above involve trial representation, rather than legal research and related services provided by a school-based clinic such as the Prison Research Council. The Council's practice is of a more limited nature, precisely in order to eliminate such dangers.

In a limited-practice clinic such as the Council, students are exercising skills much less foreign to them and much less complex than those demanded of a trial lawyer. The law student in a properly guided limited-practice clinic has no great difficulty in maintaining a professionally competent performance level over the range of activities in which he engages. To reiterate material set out in Part $I$, gathering relevant facts, the statement of questions to be researched, the research itself, the assessment of the research results and their consequences for the client, presentation of findings and conclusions to the client, and illumination of factors on which a decision should turn are all qualitysafeguarded through multi-level checks by senior law students, and thorough discussions with expert faculty. Periodicals and advance sheets keep the students abreast of the latest developments in the law. When a claim appears to warrant legal action, steps are taken to secure representation by an appropriately situated practicing lawyer.

Given the fact that the quality of the product is professionally satisfactory, the major difficulty in the resolution of the unauthorized practice problem has been overcome. Ancillary to this problem, yet not unimportant, are the considerations of professional ethics which also underlie the prohibition against unauthorized practice. One court has said:

The relation of an attorney to his client is preeminently confidential. It demands on the part of the attorney undivided allegiance, a conspicuous degree of faithfulness and disinterestedness, absolute integrity and utter renunciation of every personal advantage conflicting in any way directly or indirectly with the interests of his client. ${ }^{70}$

Law student practitioners should be subject to the same ethical standards as are full-fledged members of the profession to which they aspire. ${ }^{71}$

Assuming that the students' practice of law in clinics is desirable because a social need is fulfilled by professionally competent and pro-

69 Mancuso, Laze Students and Defender Offices, 24 LEGAL Am BrIEF CASE 242 (1966).

70 Norman's Paint Store v. Boucher, 28 UnaUthorized Practice News 82, 83 (1961), cited in Source Book 84.

71 A further problem, malpractice, is discussed separately at text accompanying notes 75-84 infra. 
fessionally responsible practitioners, it is equally desirable that this practice be accorded legitimate status by formal authorization.

The determination as to what constitutes "practice of the law" is regarded as a judicial function.

The predicate that the inherent judicial power extends to the practice of law because of the constitutional division of governmental powers, forecloses general power in the legislature over the subject. . . . In connection with qualification for bar admission the courts have upheld proper legislative police power regulations as valid minimum requirements-subject, however, to the power of the courts to prescribe additional or maximum requirements. . . . The extension of these views to the subject of unauthorized practice of law appears to be justified .... ${ }^{72}$

Thus, formal authorization may be a two-step process. In every state the applicant must meet the standards prescribed by state courts. Whenever the legislature has also set up minimum standards under the police power, they must also be met. ${ }^{73}$ As a practical matter, it is not likely that a person or group authorized by a court to practice law will be prevented from doing so by legislative exercise of the police power. Usually recognition by the courts is the sine qua non, and will be sufficient.

Problems of jurisdiction to authorize student practice, and of the scope and effect of such authorization, are presented by the fact that a school-based clinic such as the Prison Research Council in effect practices in more than one state. For example, the Council, located in Pennsylvania, may analyze a legal problem for an inmate of a Florida prison who wishes to avail himself of a federal constitutional protection. Although the actual legal work is done in Pennsylvania, reliance upon the work's quality and legal efficacy takes place in Florida, and this reliance could ultimately involve Florida courts and/or members of the Florida bar. Therefore, the Council is probably practicing law in both states. When a third or fourth state, or the federal government is added, the complexity increases.

72 G. Brand, Unauthorized Practice Decisions xi-xiii (1937) (citations omitted).

73 In a number of statutory approaches to the problem of legal practice by other than recognized attorneys, authorization is made for non-attorney practice (which would include student practice) without consulting the courts about additional requirements. E.g., MoNr. REv. CoDES ANN. \$93-6704 (1947) which provides: "Parties in justice's court may appear and act in person or by attorney; and any person, except the constable by whom the summons or jury process was served, may act as attorney." N. M. STAT. ANN. \$18-1-26 (Supp. 1967), is more restrictive:

No person shall practice law in any of the courts of this state... unless he shall have first obtained a temporary license ... or shall have been granted a certificate of admission to the bar .... Provided, however, that nothing in 
However, resolution of the problem is not difficult. The courts of a given state are generally in a position to know the quality and resources of the schools within their state. Therefore, they are better equipped than any other agency to decide whether or not a given school-based clinic should be permitted to operate. Accordingly, schoolbased clinics would be well advised to seek authorization for their program from the highest court in their home states. Once such a court has granted authorization to practice, such authorization should receive full faith and credit from federal courts and from the courts of other

this act shall be construed to prohibit persons residing beyond the limits of this state, otherwise qualified, from assisting resident counsel . . . .

The New Mexico statute would allow non-resident students to aid prisoners only if they were found to be "otherwise qualified." Some statutes regulating (and granting) the power to practice law, if they authorize activities which to the courts are objectionable as unauthorized practice, may be ruled unconstitutional. Meunier v. Bernich, 170 So. 567 (La. 1936) (statutory authorization for claims adjuster to engage in what would otherwise be unauthorized practice of law held unconstitutional.); In re Opinion of the Justices, 289 Mass. 607, 194 N.E. 313 (1935) (proposed statute authorizing banks or trust companies to furnish legal advice concerning investments, etc., would be unconstitutional); Land Title Abstract Trust Co. v. Dworken, 129 Ohio 23, 193 N.E. 650 (1934) (statute authorizing abstract and title companies to guarantee titles construed to avoid granting authority to practice law).

The relationship of the courts and legislature concerning the regulation of unauthorized practice shows a particularly interesting history in New York. N.Y. ConsT, art. VI, $\$ 8$ (1846) provided:

[The judges of the court of appeals and supreme court] shall not exercise any power of appointment to public office. Any male citizen of the age of twentyone years of age, of good moral character, and who possesses the requisite qualifications of learning and ability, shall be entitled to admisison to practice in all the courts of this state.

This section along with art. III, $\S 1$, were relied on in Cooper's Case, 22 N.Y. 67, 11 Abb. Pr. 301 (1860), which held constitutional a statute recognizing diplomates of the law school of Columbia University as having satisfied the educational and experiential qualifications for the practice of law. Any similar judicial power of recognition was expressly denied. Id. at $93,11 \mathrm{Abb}$. Pr. at 335. The amendments in N.Y. CoNST. (1869) omitted the proscription on judicial power to appoint public officers. Whether Cooper's Case, in light of these constitutional changes, is still valid, has for our purposes been rendered academic under present New York law. The latest New York statute, after proscribing the practice of law by all but persons admitted to practice as attorneys or counselors in the courts of the state, continues:

[B] ut nothing in this section shall apply ... (2) to law students in their senior or final year of law school acting under the supervision of a legal aid organization whose existence, organization or incorporation is approved by the appellate division of the supreme court of the department in which the principal office of such organization is located, when such students are acting under a program approved by the appellate division and specifying the extent to which the students may engage in activities prohibited by this statute.

N.Y. Judiciary Law $\S 484$ (McKinney 1968) L. 1965, c. 877, § 1 (eff. July 16, 1965). For illustrations of judicial action under the predecessor of this statute, see Application of Cornell Legal Aid Clinic, 26 App. Div. 2d 790, 273 N.Y.S.2d 444 (1966) (senior law students were granted judicial permission to participate in a wide range of civil litigation, but since other New York statutes provided for appointed counsel in criminal cases and sanity hearings, student participation in the latter cases was denied) ; In re Iegal Aid Society of Albany, 27 App. Div.2d 687, 277 N.Y.S.2d 632 (1967) (The court granted law students permisison to operate a community legal aid clinic under the supervision of attorneys.)

See generally American Bar Foundation, Unauthorized Practice Statute Book (1961) 
states in which clients are receiving school-based clinic aid. ${ }^{74}$ As the number of school-based clinics increases, the frequency of interstate legal aid situations will probably decrease. Often the Prison Research Council refers out-of-state prisoners to clinics closer to "home," sometimes due to the press of a large workload, and other times because the prisoner will have access to better legal aid. For example, a clinic near the prisoner may be able to interview him in person, where necessary, rather than deal with him by mail. ${ }^{75}$

On the other hand, prisoners who have had favorable dealings with one clinic may wish to maintain contact with that clinic even if they are presently confined elsewhere. This situation may foster competition among the various clinics, but competition, of course, produces higher quality work. Since there presently seems to be an abundant supply of clients, it is doubtful that any worthwhile clinic will be eliminated from the scene. In any case, inter-clinic competition seems preferable to further curtailing clients' already attenuated access to legal assistance by restricting them to correspondence only with in-state clinics.

Recognition of school-based clinics by local and foreign courts should be conditioned upon student assumption of professional, ethical, and scholarly responsibilities, perhaps by taking an oath similar to that administered to new members of the bar, or by signing a statement to similar effect. ${ }^{78}$

One important component of professional responsibility shouldered by the lawyer is tort liability for professional lapses. The clinic situation presents two new questions: Should there be liability for negligence, and, if so, who should be liable?

74 The full faith and credit clause of the Federal Constitution does not mandate that admission to the bar in one state automatically permits one to practice in another. It is true that a member of a bar of one state may be admitted to the bar of another without examination, but this is a matter of reciprocity "which is usually made to depend upon the attorney having practiced a certain number of years in his former state, being a member of that state's bar in good standings [sic] ..." American Bar Association Research Memorandum Series No. 1, Admission of Nonresident Attorneys Pro Hac Vice in State Courts and the District of Columbia, Sept. 1958. "Full faith and credit" as it is used here is not the constitutional concept, but a principle of reciprocity that is dependent on the willingness of individual state courts to accept it.

If the states will not grant reciprocity, an alternative is to seek authorization directly in each state. However, this may be prohibitively expensive. Where reciprocity is not granted, the Council may have to refuse help to prisoners in that state.

75 This is advantageous, of course, only if the clinic chooses to engage in personal contact rather than to work through correspondence. Text at pp. 972-73 supra.

76 The various court rules and statutes permitting law students to practice law contain no reference to any formal assumption of professional responsibility. This author believes that this formal step is better included than excluded; it would serve to enhance the attitude of dedication to professional competence which should characterize every participant in a school-based clinic. 
From the clinic point of view, it would obviously be desirable to avoid malpractice liability altogether. It is unlikely that malpractice insurance would be available to a school-based clinic through normal commercial channels, and it is questionable whether many schools are in a position to provide funds to satisfy substantial malpractice judgments. ${ }^{77}$ Despite such difficulties, there is no satisfactory rationale for avoiding liability for clinic error. Prosser states that "all of the arguments in favor of [charitable] immunity [have been] demolished . . . completely," that the immunity is in "full retreat," and that one may expect its "virtual disappearance from American law." "8 As charitable immunity disappears, and is replaced by liability for fault, arguments for granting immunity from liability to law school clinics becomes less persuasive. One solution to the clinic malpractice problem is to redefine the standard of care to which student practitioners are held, thereby reducing the level of the client's reasonable expectation.

The Council, as noted previously, ${ }^{79}$ is careful to point out in various ways that it is a law student activity, and that clients are served by students, not lawyers. The Council does not interpret this as a "waiver" of any sort, ${ }^{80}$ but does feel that the client who is aware of the nature of the service better knows what he may reasonably expect. While he might prefer Edward Bennett Williams or F. Lee Bailey, he knows that whatever benefit he might receive will be the product of student labor-competent-but still student labor.

Prosser points out (in the context of hospitals) that patients of clinics do not "in reality consent to be treated with negligence; and those who assume to render gratuitous assistance are held in general to a standard of reasonable conduct in doing so." 81 Prosser also states that

[p]rofessional men in general, and those who undertake any work calling for a special skill, are required not only to exercise reasonable care in what they do, but also to possess a standard minimum of special knowledge and ability. . $\cdot$. [This is] undoubtedly true of . . attorneys ... ${ }^{82}$

$\mathbf{7 7}$ In an attempt to determine the role malpractice liability plays in the activities of other clinics, the Prison Research Council queried a number of them. Communityand agency-associated clinics apparently feel that their practicing attorneys' ordinary malpractice insurance provides adequate coverage, since work therein typically proceeds on the law-clerk model. No school-based clinic with which the Prison Research Council corresponded had established a position on, or taken steps to protect against, malpractice liability, other than to try to be as careful as possible in doing the work at hand.

78 W. Prosser, The LaW of Torts 1023-24 (3d ed. 1964).

79 Text accompanying note 25 supra.

80 For a discussion of the charitable immunity "waiver theory" see W. Prosser, supra note 77 , at 1021 .

81 Id. (footnotes omitted).

82 Id. 164 (footnote omitted). 
While one may complain that "the good Samaritan who tries to help may find himself mulcted in damages, while the priest and the Levite who pass by on the other side go on their cheerful way rejoicing," 83 Prosser feels that

[i]t is quite possible that this obligation of reasonable care under all the circumstances provides all the limitation [of mulcting] that is really necessary. The defendant is never required to do more than is reasonable . . . ${ }^{84}$

The same ought to be equally true, mutatis mutandis, of law students. By limiting the nature of the clinic's practice, the students have limited the standard minimum of special knowledge and ability to one which a year or two of law school can adequately provide. Perhaps this standard should be articulated in some detail over the range of clinic activities, and presented in some way to the prospective client, so that he will have a more accurate idea of what to expect in the way of services and level of performance.

A clinic can begin to define reasonable care by examining malpractice standards for practicing attorneys and adapting the standard to the clinic situation. One member of the clinic should assume the responsibility for keeping abreast of developments in the legal malpractice field, thus keeping the clinic practice informed of, and in conformity with, developing law. At periodic clinic meetings, which should be held frequently, problems of clinic practice should be aired. Studying established standards of care, watching for new developments, and consulting with the faculty advisor should enable the clinic to anticipate the standard of care to which it would be held by a court of law. A written manual of standard operating procedures should be developed and updated continually. In problem situations in which the decisions to be made are not overly technical, clients should be told not only the results of clinic activity, but how they were achieved, so that shortcomings, if any, are brought to light while corrections may still be made. ${ }^{85}$ Through group discussion and the resulting articulation of standard procedures, unreasonably lax standards may be corrected. Furthermore, the standards set by the clinics themselves may provide useful guidance to the courts if they are forced to formulate a standard of reasonable student conduct in cases of clinic malpractice.

83 Id. 339.

84 Id. 343 (footnotes omitted).

85 The Prison Research Council has more than once been given useful leads to solutions of problems by clients themselves, who are kept up to date (via the grapevine) on the results of cases, hearings, and other developments having a bearing on pending problems. Experience often teaches prisoners the way through the maze of bureaucratic procedures involved in getting court records, parole board notices, detainer information, and the like. 
Until some sort of clinic malpractice insurance is developed, joint and several liability will be imposed on all those whose work on the improperly done clinic file helped to cause the damage. Such a result has the virtue of placing liability upon those who have the best opportunity to prevent the injury, and it would spread liability in most cases among several, if not many, people. This is a burden which a law student who seeks the benefits of clinic participation should shoulder willingly, albeit soberly. It is the client's best assurance that after turning over his affairs to a volunteer group of law students, he is truly a "client" of serious individuals who take a professional, responsible approach to the opportunity which his case offers them. It assures the clinic that its staff will not be made up of dilettantes who want to add an extracurricular activity to their resumé provided the costs are not too great. It is a concrete step toward a real feeling of professional responsibility, the development of which is, from both the student's and school's points of view, a primary goal of the program.

\section{Conclusion}

Born only three years ago, the Prison Research Council of the University of Pennsylvania Law School is flourishing. The clinic affords students an opportunity to increase their knowledge of criminal law, to develop an ability to ascertain the problem in a given situation, to learn to solve that problem with as little wasted effort as possible, to shoulder the responsibility of a practicing attorney, and, most important, to experience the satisfaction of aiding a segment of society previously cut off from legal help.

Although the Council is not a means of immediate release for the vast majority of prisoners, it serves as a device to clarify and explain what the judicial system has done to them, and why. For many, it may remove lingering doubts, and help to set their sights on rehabilitation. Because prisoners are not wealthy, in most instances, they cannot afford lawyers. And beyond the first appeal, they are denied access to an attorney provided free by the public. Prisoners remain one of the most forlorn and neglected classes of society.

Other schools with legal aid clinics have chosen to expand the scope of their activity to offer a multitude of legal services. ${ }^{86}$ Whether

86 Harvard Law School, for example, has had the Harvard Legal Aid Bureau since 1913. Recently, there has been a new emphasis on poverty law. Law students are working in conjunction with Fair Housing, Inc., to improve housing in ghetto areas. Harvard students also practice before the Massachusetts Commission Against Discrimination; counsel small businessmen; work in mental hospitals, interviewing and advising patients and hospital; represent those who seek release from state mental hospitals (subject to attorney supervision); and practice before the Office Audit Division in the Boston Internal Revenue Service office in a pilot project. For a description of the Harvard program, see Metzger, The Bureau's Minor Revolution, 20 HARV. L. SchOOL Bull. 2 (1969). 
or not a new clinic should concentrate on one area-prisoners, for example, or diversify, is debatable. Other schools may decide that the benefits of personal consultation exceed the liabilities, that students should represent prisoners at trials, or that a community-based clinic is preferable to one based in the law school. For reasons given earlier the University of Pennsylvania Law School has made its choices, but they are not so clearly correct as to be beyond challenge. The precise structure of the legal aid clinics is not nearly so important as the philosophy of equal justice that underlies their creation.

Law students have remained an untapped source of legal aid in most schools. Yet, they have the idealism, enthusiasm, and energy to accomplish a great deal. Perhaps it is only fiitting that those who are being trained in the law should offer to help those who have suffered most at the bar of justice. Shouldering a responsibility that is almost as great as that of a practicing lawyer, the student must temper his vivacity and control his emotions, or face possible liability for rash conduct.

Trained to research and forced to think with analysis and reflection, law students have the capabilities to staff a clinic. The degree of success and satisfaction a clinic like the Prison Research Council can provide is limited only by the time, effort, and creative energy that the members contribute. 